\title{
Study approach and step by step development of a fish-based multimetric index for reservoirs: a case study presentation from a neotropical cascade system
}

\author{
Abordagem de estudo e passo a passo para o desenvolvimento de um índice
} multimétrico baseado em peixes para reservatórios: apresentação de um estudo de caso de um sistema neotropical em cascata

\section{Maria Letizia Petesse}

${ }^{1}$ Programa de Pós-graduação em Aquicultura e Pesca, Instituto de Pesca de São Paulo, Agência Paulista de Tecnologia dos Agronegócios - APTA, Secretaria de Agricultura e Abastecimento SAA, Avenida Francisco Matarazzo, 455, Perdizes, CEP 05001-900, São Paulo, SP, Brasil

*e-mail: mlpetesse@gmail.com

Cite as: Petesse, M.L. Study approach and step by step development of a fish-based multimetric index for reservoirs: a case study presentation from a neotropical cascade system. Acta Limnologica Brasiliensia, 2018, vol. 30, e305.

Abstract: Aim: The present paper approached some issues related to the construction and adaptation of the Reservoir Fish Assemblage Index (RFAI). Method: the case study presents the step by step construction of the multimetric index adopted for the Tietê cascade reservoir system, and it is discussed the comparison between discrete and continuous scoring criteria. Results: The main questions related to the adaptation of multimetric indexes to reservoir were synthesized as: $\mathrm{i}$ - terminology question; ii - representative fish sampling; iii - reference condition. The construction of the RFAI for the Tietê cascade reservoir system resulted in seven steps, and the continuous scoring criterion showed to increase the accuracy of the final index when compared to the discrete scoring especially for the most degraded environment. Conclusion: Biological criteria for the assessment of aquatic ecosystems are widely recognized and accepted by scientific community. The increasing value of water resource makes reservoirs important object of scientific and social interest, justifying the definition of proper tools for their assessment and monitoring. Among the available tools, the multimetric approach is one of the most popular. The observed results showed the validity of the approach also for artificial environments, expecting for its official incorporation in biomonitoring programs in Brazil.

Keywords: biomonitoring; artificial environment; tropical area; icthyofauna.

Resumo: Objetivo: Neste trabalho são abordados alguns assuntos relacionados com a construçáo e adaptação do índice da assembleia de peixes em reservatório (IAPR). Método: $\mathrm{O}$ passo a passo da construção do índice multimétrico adaptado para o sistema de reservatórios em cascata do Rio Tietê (SP, Brasil) é apresentado como caso de estudo e a comparação entre critério de pontuação discreto e continuo é discutida. Resultados: As principais questôes relacionadas com a adaptação de índices multimétricos para reservatórios são: $\mathrm{i}$ - questão de terminologia; ii- amostragem representativa da ictiofauna; iii - condiçóes de referência. A construção do Índice da Assembleia de Peixes em Reservatório (IAPR) para o sistema de reservatórios em cascata do Rio Tietê é descrita em sete passos e o critério de pontuação continua mostrou aumentar a precisão do índice em relaçáo à pontuação discreta, especialmente no caso de ambientes mais degradados. Conclusáo: $\mathrm{O}$ uso de critérios biológicos para avaliação das condições dos ecossistemas aquáticos é amplamente reconhecido e aceito 
pela comunidade cientifica. O crescente valor estratégico da água faz dos reservatórios importantes objetos de interesse cientifico e social, justificando a necessidade de definir ferramentas adequadas de avaliaçáo e monitoramento. Entre as várias ferramentas disponíveis, a abordagem multimétrica é atualmente uma das mais populares. Os resultados observados mostram a validade da abordagem também para ambientes artificiais, permitindo auspiciar a sua incorporação em programas oficiais de biomonitoramento no Brasil.

Palavras chaves: biomonitoramento; ambientes artificiais; área tropical; ictiofauna.

\section{Introduction}

The Index of Biotic Integrity (IBI) (Karr, 1981) is one of the most popular tools for monitoring and diagnosis of aquatic environments in the world. It was proposed in 1981 responding to the requirement of the "Clean Water Act" (1972), which aim was "... restoring and maintaining the chemical, physical and biological integrity of the Nation's waters" (EPA, 2017, p. 2). It is a multimetric index where each metric represents an ecological attribute of the biological assemblages that changes in a predictable way with the increasing or decreasing of degradation (Karr \& Dudley, 1981). The assessment of environmental conditions is made by comparing the metrics of the biological assemblages at the study site with that of a preserved site located in the same ecoregion. The multimetric approach is a very useful tool and may be applied to different environments and groups of organisms. In scientific literature there are examples of adaptation to small and big river (Karr et al., 1986; Emery et al., 2003), lakes (Uzarski et al., 2005; Irz et al., 2006; Beck \& Hatch, 2009), reservoirs (Jennings et al., 1995; McDonough \& Hickman, 1999), estuaries, wetland, and marine coastal waters (Delpech et al., 2010). In relation to organisms, the most used are the phytoplankton (Hill et al., 2003; Wu et al., 2012), macroinvertebrate (Klemm et al., 2002; Blocksom \& Johnson, 2009), fish (McCormick at al., 2001; Magalhães et al., 2008; Terra et al., 2013), and macrophytes (Ferreira et al., 2005; Beck et al., 2010). Some multi-taxon combinations have been proposed, such as phyto-benthos and macroinvertebrates, fish and macrophytes, fish and amphibians (Abbasi \& Abbasi, 2012; Lougheed et al., 2007; Everard et al., 2011). Most research, however, focused on fish (Ruaro \& Gubiani, 2013). Fishes are historically considered good indicators because they are sensitive, persistent, recover quickly from natural disturbances, integrate the negative effects of environmental degradation, and they are long-living organisms (Fausch et al., 1990). Thus, they are indicators of long-term environmental stresses, and aspects related to taxonomic classification, distribution, life cycle, and tolerance are known for many species. Another advantage is that body size and weight data may be easily obtained in the field, decreasing the processing time at laboratory. Moreover, fish are suitable to evaluate the social costs of degradation because of human empathy and the economic benefit provided from them.

Dams are among the greatest human impacts on the aquatic ecosystem, but the use of biological criteria to assess the reservoir ecosystem conditions is still rare. The Society is highly dependent from ecosystem services, and the need for multiple water uses is increasing the strategic value of water. Maintaining or restoring the health of these ecosystems is essential to respond to society's current and future demand. For this purpose, the development of adequate assessment tools cannot be delayed. In fact, reservoirs are part of the landscape in many countries around the world, and their impact on the river ecosystem can not be reversed in the short or medium time. In this context, Brazil is no exception with more than 600 large dams occupying its territory (Agostinho et al., 2007). The demand for hydroelectric production led to the transformation of many rivers into cascade of reservoirs, as the case of the Paraná River and its main tributaries.

Some issues related to the adaptation of the multimetric index as: $\mathrm{i}$ - terminology question; ii - representative fish sampling and iii - reference condition were approached in this study, and the step by step index construction adopted for the Tietê cascade reservoir system is presented as case study.

\section{Terminology Question}

In relation to terminology, Jennings et al. (1995) states that reservoirs are man-made environments, so the term "biological integrity" is not proper for them. As alternative, they suggest "Reservoir Fish Assemblage Index" (RFAI) as most suitable. The term "biological integrity" should be reserved only to situations close to pristine conditions.

\section{Representative Fish Sampling}

This point is related to the difficulty to obtain a "representative fish sampling". It is a common problem to all lentic habitats, but in reservoirs it 
is magnified by the peculiar characteristics of these environments. In fact, reservoirs are heterogeneous in three space dimensions (longitudinal, transversal, and vertical), hybrid between rivers and lakes, and with the hydraulic cycle independent from the natural river flow, because it is imposed by the requirements of the electric production or by the water uses (Straškraba $\&$ Tundisi, 1999). Thus, reservoir requires an extremely careful sampling design aiming the exploration of all the reservoir zones and habitats. Systematic or stratified probabilistic designs are the most common strategies, however, depending on the number of reservoirs including in the study, more complex designs are proposed, such as the General Random Tessellation Stratified Design (GRTS). In this case, the GRTS allows a more balanced distribution of sampling sites in the ecoregion (Stevens Junior \& Olsen, 2004).

Sampling period and fish sampling gears should be appropriately chosen. In the case of sampling period, the reservoir hydraulic cycle may be known. Normally, hydroelectric reservoirs are classified as accumulation or run-of-the-river. Accumulation reservoirs have a regulatory function assuring the hydroelectric production target along the cascade system, independently of seasonal rains or river flood natural regimes. Thus, they display higher water level fluctuation during the year, unlike the run-of-the-rivers. In this way, it is recommended to concentrate the fish sampling when the hydraulic cycle is more stable to limit the index variability and allow the comparison among reservoirs with different hydraulic management in the same system or ecoregion. In the case of the Tietê reservoir system, for example, Barra Bonita reservoir (Figure 1a) displays higher level fluctuation than Bariri (Figure 1b), thus the better index period for these reservoirs is between August and September or February and March.

Considering the sampling gear, according to Karr et al. (1986), the sampling methods must be standardized and the relative abundances of the fish populations should be representative of its true values without bias toward taxa or fish size. Therefore, the fishing effort may be adapted to the study environment, and little selective fishing gear or a combination of gears may be used to maximize the capture. The most common fishing gears used in reservoirs are electrofishing equipment and gillnets. In Brazil, most experimental fishing in reservoirs has been carried out by gillnet set with different mesh sizes (i.e. from 3 to $12 \mathrm{~cm}$ between opposite knots) (Terra \& Araújo, 2011; Petesse et al., 2014). According to Jennings et al. (1995), the variability
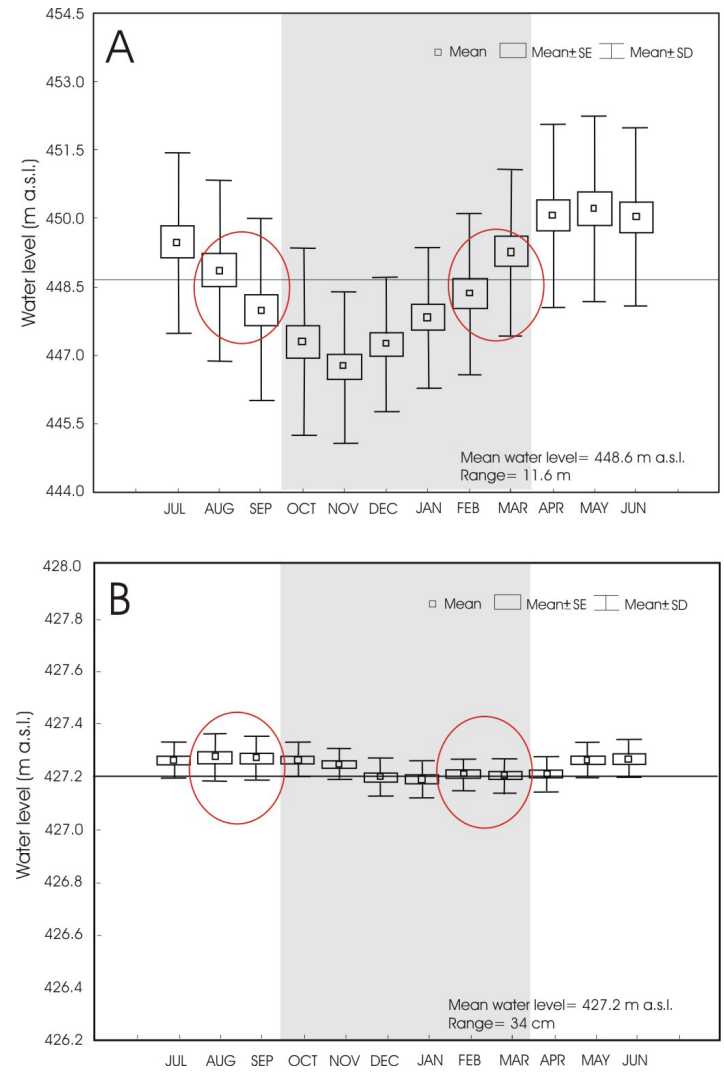

Figure 1. Hydraulic cycle of Barra Bonita (A) and Bariri (B) reservoirs. Barra Bonita is an accumulation reservoir, and Bariri is a run-of-the-river reservoir. The solid horizontal line is the yearly mean water level ( $m$ a.s.l.). Range is the yearly water level fluctuation. Red circles indicate the best "index period" corresponding to comparable hydraulic conditions through the system (August-September or February-March). Shadow area: rainy season (October-March). Barra Bonita hydraulic series: 1969-2002; Bariri hydraulic series: 1988-2008.

of RFAI increases when the effort is little. Thus, they recommend concentrate the sampling of fish assemblages at the shoreline and increase the fishing effort (between 15-20 electro-fishing runs and set of 10-12 different gillnet mesh sizes). In fact, in reservoirs the shoreline habitat is more complex than the pelagic, due to the presence of macrophyte beds, riparian vegetation or logs of impounded trees that provide food and shelter for fish (Jennings et al., 1999). Sample rarefaction curves obtained using non-parametric estimator of species richness (Jackknife, Chao 1 or Chao 2) may be applied to verify the efficiency of the sampling effort.

\section{Reference Conditions}

Reference conditions, in its original definition, refer to a pristine environment where the evolutionary conditions of organisms are preserved 
out of anthropogenic effects (Karr \& Chu, 1999). Measuring the deviation from the reference condition means to measure the degradation level of the system as a consequence of anthropogenic action. Therefore, keeping integrity means saving the living system, and it allows the maintenance of ecosystem services which we depend on. Considering the difficulty to find truly pristine environments, Stoddard et al. (2006) define five types of reference conditions for multimetric assessment in the United States:

\section{Minimally Disturbed Condition (MDC):} refers to an environmental situation without significant expression of human impact. In this condition, we admit that part of the observed variability is due to the anthropic interference, but it does not affect the natural development of organisms. It is our best approximation to the pristine condition.

2.Least Disturbed Condition (LDC): this condition is related to the best environmental physical and chemical condition observed in the study area. Considering that environmental conditions may change (worsen or improve) in time, also the "Least Disturbed Condition" changes, so it requires continuous assessment.

3. Best attainable Condition (BAC): refers to the "expected" ecological condition, when the best possible management practices are applied. It is a theoretical condition and represents the expected environmental recovery, when management, technological resources, and good land use practices are applied.

4.Historical Condition (HC): describes the environmental condition at a given period in the past. It is a good reference if the chosen historical moment is prior to any human disturbance practices (i.e.: pre-Intensive agriculture, pre-Industrial age, North American pre-Colombian era).

5.Professional judgment (PJ): it is based on the "subjective" interpretation of the observed conditions by an expert familiar with the study area.

A different approach is proposed by the European Water Framework Directive (EC, 2000). The Directive referring to artificial or highly modified environments that cannot return to their original conditions, indicates the Good Ecological Potential (GEP) as the recovery objective (Figure 2).

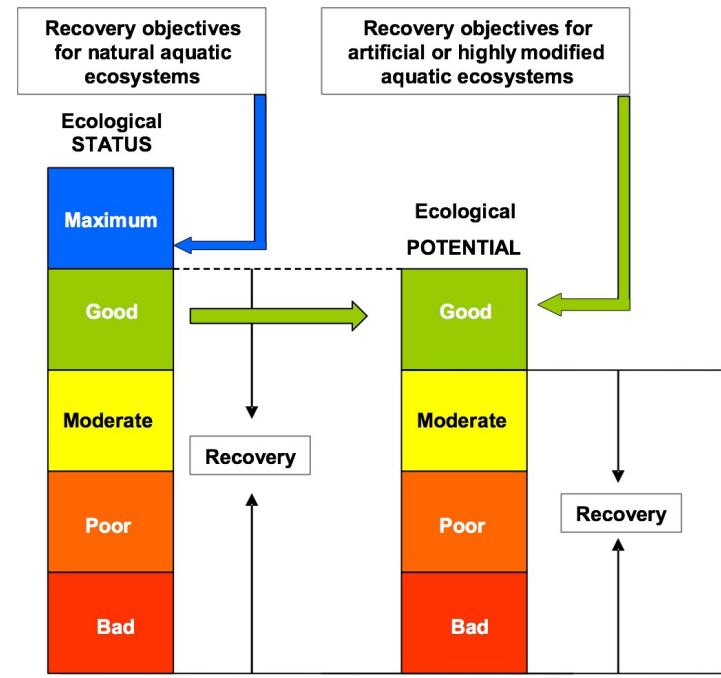

Figure 2. Comparison between Ecological Status (for natural ecosystem) and Ecological Potential (for artificial or highly modified environments) from the European WFD (EC, 2000).

The GEP derives from ecological state levels of natural environments, for which the recovery objective is the Maximum Ecological Status (MES) (Borja \& Elliott, 2007). In theory, the GEP to be adopted for reservoirs or highly modified environments, may be that of the most similar corresponding natural environment. However, considering that reservoirs are hybrid between river and lake, it is not clear if the GEP to be adopted is that of natural rivers or lakes. Irz et al. (2006), performed a comparative study among lakes, rivers, and reservoirs in France to answer the question. The conclusion showed that reservoirs cannot be considered similar to lakes a priori, reinforcing the need to define specific reference objectives for these environments (Petesse et al. 2014). In practice, the best observed condition (Least Disturbed Condition) is used as reference for reservoir, and to clearly show the variability of the environmental conditions within or among reservoir, it is useful to include sites minimally and highly impacted (Joy \& Death, 2004).

\section{Advantages of the Multimetric Approach}

Multimetric indices are effective tools for environmental diagnosis and monitoring purpose. They may be applied to all types of monitoring programs (general, operational, investigative), allowing the identification of sites with high integrity or degraded conditions. Multimetric indices may also be used to assess the recovering processes, as well as the sustainable use of natural resources, and in the management or policy planning about maintenance 
and conservation of aquatic ecosystems. Another advantage of biomonitoring is that, depending on the organism, we may have responses at different time scale satisfying short, medium, and long term assessment requirements. Unlike physical and chemical variables, that provide information only at the moment of the sampling time, organisms are persistent and allow an integrated view of the environmental conditions (Abbasi \& Abbasi, 2012). At this purpose, for the general monitoring program, the Water Framework Directive (EC, 2000) suggests a different sampling frequency according to the taxonomic group of biological elements. For phytoplankton, it suggest a sampling frequency every six-month; for macroinvertebrates every 1-3 years; for macrophytes and fish every 3 years. Also, depending on the environment type, it is possible to choose the biotic assemblages best suited for the monitoring objective (EC, 2005).

\section{Case Study}

The study of Petesse et al. (2014) on the cascade reservoir system of the Tietê River (SP, Brazil) is an example of the adaptation of multimetric approach to neotropical reservoirs. In this study, the Reservoir Fish Assemblage Index (RFAI) was adapted to five out six reservoirs of the cascade system. The studied reservoirs ordered from upstream to downstream, were: Barra Bonita, Bariri, Ibitinga, Promissão, and Nova Avanhandava. The study shows the step by step index construction, identifies the "index period" (the best sampling period - dry or rainy season), and tested the effect of the measurement unit of the metrics (fish number or weight) on the index performance. Thus, two indexes were developed and compared: the RFAI-N with metrics calculated from the fish abundance, and the RFAI-W with metrics calculated from the fish weight.

A total of 72 sites (24 in Barra Bonita, 6 in Bariri, 6 in Ibitinga, 24 in Promissão, and 12 in Nova Avanhandava) were selected for the ichthyofauna sampling. The sample design was stratified by "zone" (fluvial, transition and lentic) in each reservoir, and within each zone, three different habitats were randomly selected: reservoir shoreline (L), mouth of tributaries (D), and center (C).

The sampling methodology was standardized by using a set of 10 gillnets with mesh sizes from 3 to $12 \mathrm{~cm}$ between opposing knots and "covo". The latter, that is a fish trap, was used to sample fish species with little body size living close to macrophytes beds. At each sampling site, some physico-chemical and environmental variables were recorded (see Petesse et al., 2014 for details). Samples were collected at two seasons: in dry period (August-September) and in rainy period (February).

Sample rarefaction curves (Krebs, 1999) by reservoir showed a tendency to stabilize in all the reservoirs except Bariri, indicating that the sampling effort was sufficient in the complex (Figure 3).

The RFAI construction process followed the steps summarized in Figure 4.
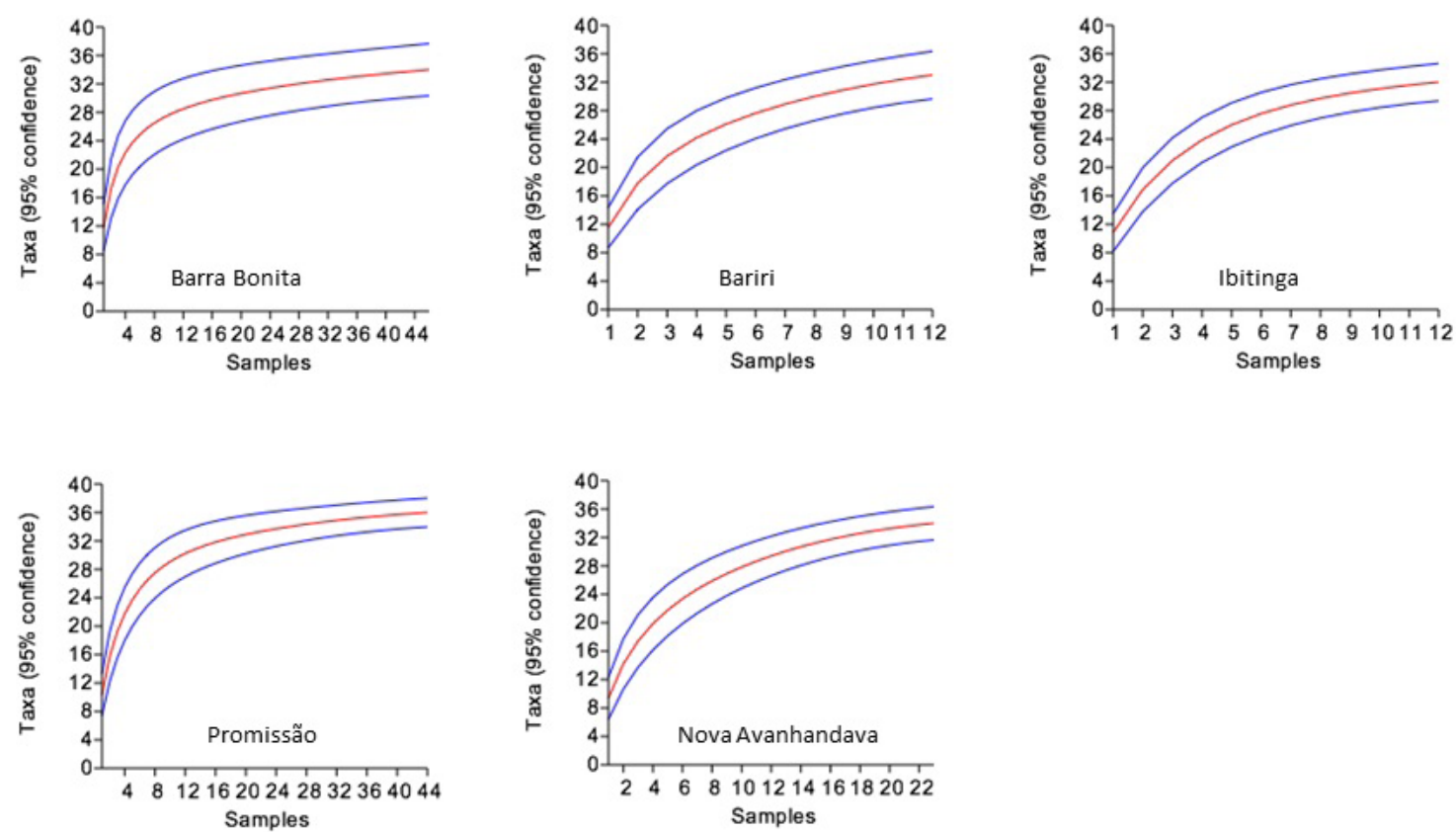

Figure 3. Rarefaction curves by samples based on the non-parametric Chao2 estimator (Colwell et al., 2004) applied to species presence/absence data of the Tietê cascade reservoir system (SP, Brazil). Blue lines =95\% confidence limits. 
Step 1: Division of the original data set in Development and Validation set. The development set is used to identify sites in best conditions, select the candidate metrics, score the selected metrics, and calculate the final index. The Validation set is as an independent data set; it is randomly extracted from the original data set and used to evaluate the performance of metrics, and of the final index (Hughes et al., 1998; Astin, 2007; Magalhães et al., 2008).

Step 2: Candidate metrics. All candidate metrics represent an ecological attribute of fish assemblages that change in a predicable way with the degradation of the aquatic environment (Karr et al., 1986; Karr, 2006). Metrics were grouped in: $i$ - species richness and composition, ii - abundance and weight, iii - trophic composition, iv - health/reproductive and behavioural traits. Based on these criteria, 24 metrics were individuated for the Tietê reservoir system.

Step 3: Metric selection. Metric selection occurs through the sequential application of several statistical tests (Oliveira et al., 2008). According to Whittier (1999), it avoids subjectivity in the choice of metrics. The tests applied to the Tietê

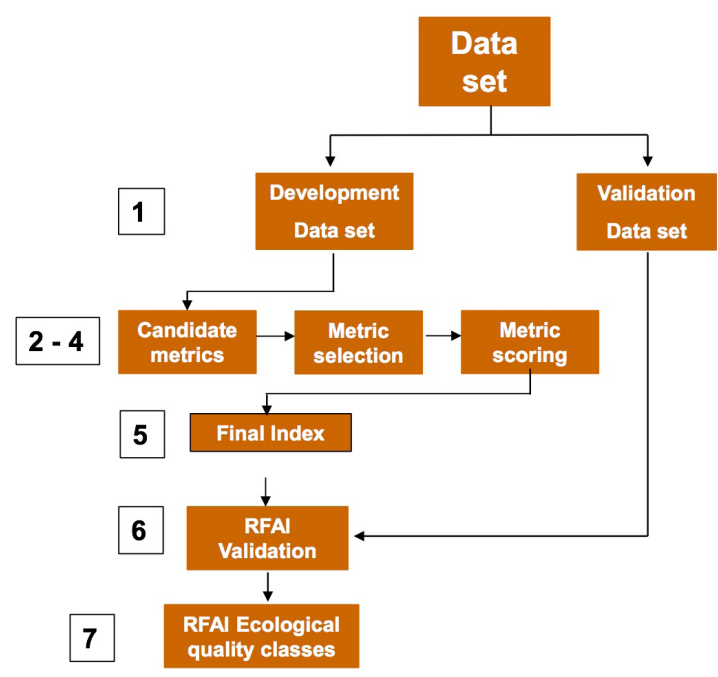

Figure 4. Steps (1 to 7) for fish-multimetric index construction. reservoir system, were: $\mathrm{i}$ - the range test, ii - the responsiveness test, and iii - the redundancy test. For details on the exclusion criteria followed by each test, see Petesse et al. (2014). Finally, nine metrics were selected to enter in the final indexes. Four metrics were common to the two indices (RFAI-N and RFAI-W), and five specific to each of them (Table 1).

Step 4: Scoring criterion. The scoring criterion is an important step, once it allows to join metrics originally measured in different units, enabling the final index calculation. Two different kinds of scoring criteria are available: the discrete and the continuous. In the Tietê case study, the discrete criterion was applied according to Karr (1981). Thus, the interval between $5^{\text {th }}$ and $95^{\text {th }}$ percentiles of the metric values was trisected and the discrete score of 1,3 or 5 was applied to the metric raw value, depending on whether it deviates greatly from (score 1), somewhat from (score 3), or if comparable to the reference value (score 5). In this way, values in the upper third, for metric that decreased with degradation, received score 5 , and that in the lower third, received score 1 . An opposite scoring order was used in the case of metric that increased with degradation (Gerritsen et al., 2003).

Step 5: Final index. The final index was obtained by summing the partial scores of each metric. The RFAI-N and RFAI-W indices varied from a minimum 9 to a maximum 45. Both were highly correlated to each other and able to detect a clear longitudinal recovery gradient among the five reservoirs. Barra Bonita presented the worse condition and Nova Avanhandava the best (Table 2).

Step 6: Validation. The indices ability to reproduce similar scores from an independent data set was verified with the aid of the Validation Set (VS) initially separated from the original data set. The RFAI-VS was obtained using the same metrics and scoring criteria previously defined by the Development Set (DS). Two validation processes were performed: one for the RFAI-N and one for the RFAI-W. The indices comparison did not show

Table 1. Selected metrics for RFAI-N and RFAI-W for the Tietê cascade reservoir system (see Petesse et al., 2014 for details).

\begin{tabular}{ccc}
\hline Metrics common to RFAl-N and RFAI-W & RFAl-N metrics & RFAI-W metrics \\
\hline Number of tolerant species & Number of non-native individuals & Weight of non-native individuals \\
$\%$ of dominance & Number of native individuals & Weight of native individuals \\
$\%$ of individuals with lesion or anomalies & $\%$ of omnivores by number & $\%$ of omnivores by weight \\
Number of migratory species & $\%$ of top carnivores by number & \%of top carnivores by weight \\
& $\%$ of iliophagous by number & \% of iliophagous by weight \\
\hline
\end{tabular}


a significant statistical difference, thus validating the index process construction. The RFAI-N and RFAI-W indices were also positively correlated with the $I^{\text {st }}$ axis of the principal component analysis (PCA) based on the physical-chemical and environmental variables recorded in the field, which revealed a clear longitudinal improvement gradient.

Step 7: Quality classes. From the final index, four quality classes were defined: very poor, poor, fair, and good. The results showed that about $50 \%$ of Barra Bonita and Bariri sampling sites were in poor condition, and despite the improvement in reservoir biotic conditions from upstream to downstream, only one site in the Promissão reservoir, and two sites in the Nova Avanhandava reservoir (only for the RFAI-W) showed good conditions. The longitudinal improvement revealed by the indices was previously observed by CETESB
(2017) and Barbosa et al. (1999) on water quality variables. However, considering that no sites were classified as "very poor" by the RFAI, three quality classes may be used, being: impaired, moderately impaired, and acceptable, as adopted by Terra $\&$ Araújo (2011).

\section{Scoring Criteria: Continuous vs Discrete}

Although many indices use a discrete scoring some authors (Hughes et al., 1998; Klemm et al., 2003; Blocksom \& Johnson, 2009) suggest that the continuous scoring is more effective, because it increases the index accuracy thus reflecting the observed conditions clearly.

To verify this aspect in the case of the Tietê cascade reservoir system, the metric score was recalculated using the continuous criterion, and

Table 2. Mean values, standard deviation, minimum and maximum values of the final RFAI-N and RFAI-W for the Tietê cascade reservoir system (see Petesse et al., 2014 for details).

\begin{tabular}{|c|c|c|c|c|c|c|}
\hline & \multicolumn{3}{|c|}{ RFAI-N } & \multicolumn{3}{|c|}{ RFAI-W } \\
\hline & Mean ( \pm SD) & Minimum & Maximum & Mean (士SD) & Minimum & Maximum \\
\hline Barra Bonita & $48.2 \pm 6.8$ & 36.9 & 60.6 & $48.5 \pm 5.7$ & 39.6 & 61.7 \\
\hline Bariri & $51.5 \pm 8.2$ & 42.3 & 62.2 & $54.4 \pm 9.6$ & 42.9 & 65.7 \\
\hline Ibitinga & $54.2 \pm 8.4$ & 41.6 & 63.3 & $57.3 \pm 7.7$ & 44.9 & 64.9 \\
\hline Promissão & $55.4 \pm 6.5$ & 42.8 & 67.1 & $58.3 \pm 7.2$ & 43.3 & 71.9 \\
\hline Nova Avanhandava & $60.0 \pm 5.9$ & 50.6 & 70.0 & $63.7 \pm 7.0$ & 55.2 & 77.6 \\
\hline
\end{tabular}
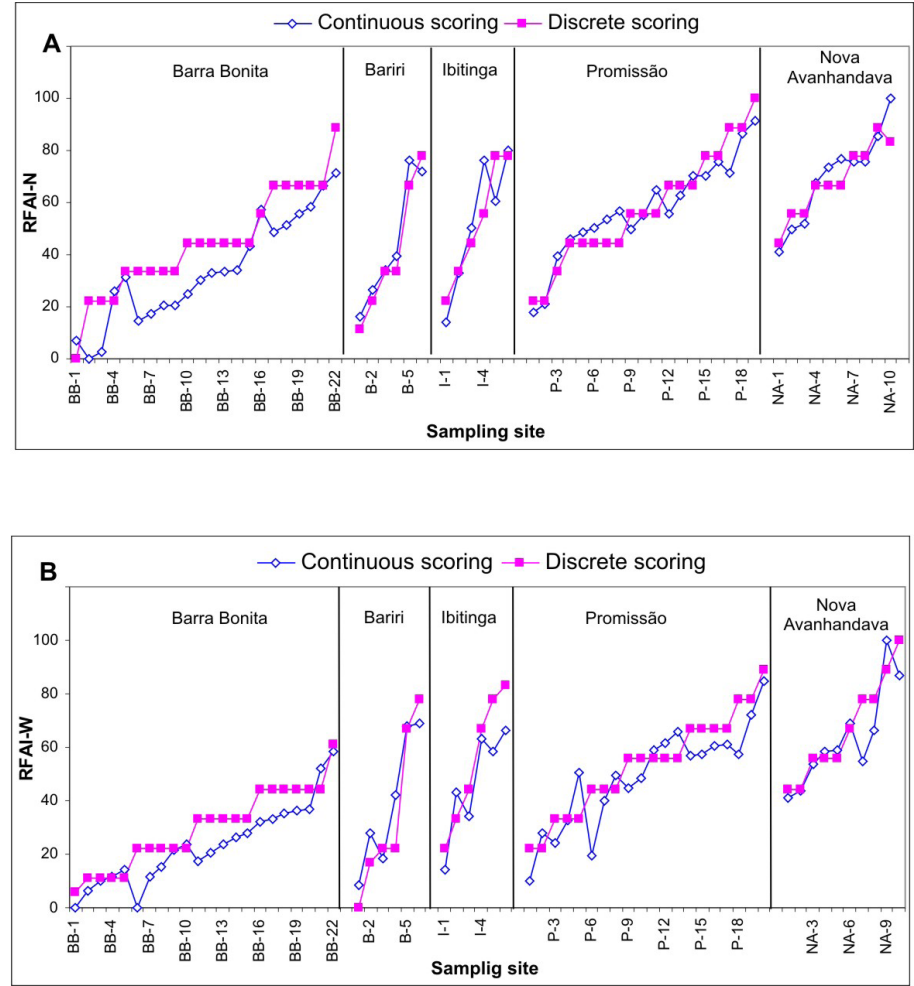

Figure 5. Comparison between standardized continuous and discrete scoring for RFAI-N (A) and RFAI-W (B). 
the final indices compared with the discrete ones. For this purpose, the index scales from continuous and discrete criterion were standardized following Angradi et al. (2009). The continuous scores were assigned following Klemm et al. (2003), Blocksom \& Johnson (2009), and Terra et al. (2013). In particular for metrics that decrease with impairment, values upper the $95^{\text {th }}$ percentile were scored 10 , and values lower the $5^{\text {th }}$ percentile received score 0 . Metric values in the interval $5^{\text {th }}-95^{\text {th }}$ were linearly interpolated. An inverted score was assigned in case of metrics that increase with degradation.

The indices comparisons did not show any strong difference among the distribution values of the two scoring criteria, but Barra Bonita reservoir. Analysing the index value by sampling site, we observed that discrete scoring criterion tends to overestimate the degraded environments, and slightly underestimates those in better conditions (Figure $5 \mathrm{a}$ and $\mathrm{b}$ ). The same was observed by Fore et al. (1994). It may be explained considering that all the metric values within the interval defined by discrete trisection receive the same score (1 or 3 or 5 ) independently of the observed value. It diminishes the accuracy of the final index conferring the typical format of "stair step" to the index distribution.

Comparing the indices obtained from fish abundance and weight, the RFAI-W appeared more sensitive in detecting the fish assemblage conditions, mainly in degraded environments, as in Barra Bonita reservoir. In fact, the fish assemblage at Barra Bonita reservoir is dominated by r-strategist species, opportunistic, small body-size and with fast reproductive compensation, hardly contributing to the biomass of the system (Petesse et al., 2007).

\section{Perspectives for the Use of Fish-Based Multimetric Indices in Brazil}

Brazil presents approximately 2300 species of freshwater fish corresponding to the $55 \%$ of the Neotropical fish species region (Buckup et al., 2007). New species are described every year indicating that the entire fish' biodiversity is still unknown. Therefore, studies on fish species taxonomy, biology, and ecology (composition, abundance, biomass, trophic category, age classes, migratory habit, reproductive strategy, vulnerability and resilience) must be encouraged. The higher the level of knowledge about species traits, higher will be the possibility to identify metrics that better respond to degradation. It allows the improvement of index performance, and the best discrimination of degradation causes.

The second issue for the future perspective of biomonitoring programs is related to technical-operational aspects aiming the optimization of time and costs. In this sense, substantial efforts may be addressed to field sampling protocol homogenization, standardization of sampling methodology, as well as professional trainings, and data processing techniques. These aspects are also essential for sharing data from different river basins, monitoring agencies and states.

Another issue is the definition of clear recovery targets for the artificial environment. This means classify reservoirs in homogeneous groups, but this is not easy because of their peculiar characteristics as location, morphology, size, hydraulic management, trophic state, etc. In addition, many reservoirs in the southeast of Brazil are cascade systems, so the conditions of upstream reservoir affect the conditions of downstream ones complicating the comparisons between systems in the same ecoregion.

Finally, Ruaro \& Gubiani (2013) shows that the evolution of biomonitoring tools only occurred after the approval of specific regulations in this sense. In Brazil, biomonitoring is not mandatory, and the applications of the multimetric approach for environmental diagnosis is still restrict. In fact, only the State of Minas Gerais introduced the classification of freshwater environments based on the "ecological integrity" (Resolution COPAM / CERH-MG No. 001/2008), showing the validity of the approach. Thus, we expect its incorporation in official biomonitoring programs in all Brazil states, and the definition of clear recovering objective for artificial environments.

\section{Acknowledgements}

The research Petesse et al. (2014) was supported by FAPESP (Fundação de Amparo à Pesquisa do Estado de São Paulo), grant n. 07/50985-2, inserted in Thematic Project (n. 07/50981-7) "Ecologia de Represas"-UNESP, allocated to Professor M. Petrere Jr. and Professor A.A. Agostinho. The author thanks CAPES (Coordenção de Aperfeiçoamento de Pessoal de Nível Superior) for the PNDP (Programa Nacional de Pós Doutorado) grant. Thank to the anonymous reviewers whose suggestions contributed to the improvement of this manuscript.

\section{References}

ABBASI, T. and ABBASI, S.A. Water quality indices. Great Britain: Elsevier, 2012. 
AGOSTINHO, A.A., GOMES, L.C. and PELICICE, F.M. Ecologia e manejo de recursos pesqueiros em reservatórios do Brasil. Maringá: EDUEM, 2007.

ANGRADI, T.R., PEARSON, M.S., JICHA, T.M., TAYLOR, D.L., BOLGRIEN, D.W., MOFFETT, M.F., BLOCKSOM, K.A. and HILL, B.H. Using stressor gradients to determine reference expectations for great river fish assemblages. Ecological Indicators, 2009, 9(4), 748-764. http://dx.doi.org/10.1016/j. ecolind.2008.09.007.

ASTIN, L.E. Developing biological indicators from diverse data: the Potamac Basin-wide Index of Benthic Integrity (B-IBI). Ecological Indicators, 2007, 7(4), 895-908. http://dx.doi.org/10.1016/j. ecolind.2006.09.004.

BARBOSA, F.A.R., PADISAK, J., ESPINDOLA, E.L.G., BORICS, G. and ROCHA, O. The cascading reservoir continuum concept (CRCC) and its application to the river Tietê-Basin, São Paulo State Brazil. In: J.G. Tundisi and M. Straškraba, eds. Theoretical reservoir ecology and its applications. Leiden: Backhuys Publishers, 1999, pp. 425-438.

BECK, M.W. and HATCH, L.K. A review of research on the development of lake indices of biotic integrity. Environmental Review, 2009, 17(NA), 21-44. http:// dx.doi.org/10.1139/A09-001.

BECK, M.W., HATCH, L.K., VONDRACEK, B. and VALLEY, R.D. Development of a macrophytebased index of biotic integrity for Minnesota lakes. Ecological Indicators, 2010, 10(5), 968-979. http:// dx.doi.org/10.1016/j.ecolind.2010.02.006.

BLOCKSOM, K.A. and JOHNSON, B.R. Development of a regional macroinvertebrate index for large river bioassessment. Ecological Indicators, 2009, 9(2), 313-328. http://dx.doi.org/10.1016/j. ecolind.2008.05.005.

BORJA, A. and ELLIOTT, M. What does "good ecological potential" mean, within the European Water Framework Directive? Marine Pollution Bulletin, 2007, 54(10), 1559-1564. http:// dx.doi.org/10.1016/j.marpolbul.2007.09.002. PMid:17903563.

BUCKUP, P.A., MENEZES, N.A. and GHAZZI, M.S. Catálogo das espécies de peixes de água doce do Brasil. Rio de Janeiro: Museu Nacional, 2007.

COLWELL, R.K., MAO, C.X. and CHANG, $J$. Interpolating, extrapolating, and comparing incidence-based species accumulation curves. Ecology, 2004, 85(10), 2717-2727. http://dx.doi. org/10.1890/03-0557.

COMPANHIA AMBIENTAL DO ESTADO DE SÃO PAULO - CETESB. Qualidade das águas interiores no estado de São Paulo 2016. São Paulo: CETESB, 2017. Série Relatórios.

DELPECH, C., COURRAT, A., PASQUAUD, S., LOBRY, J., LE PAPE, O., NICOLAS, D., BOËT,
P., GIRARDIN, M. and LEPAGE, M. Development of a fish-based index to assess the ecological quality of transitional waters: The case of French estuaries. Marine Pollution Bulletin, 2010, 60(6), 908-918. http://dx.doi.org/10.1016/j.marpolbul.2010.01.001. PMid:20097384.

EMERY, E.B., SIMON, T.P., MCCORMICK, F.H., ANGERMEIER, P.L., DESHON, J.E., YODER, C.O., SANDERS, R.E., PEARSON, W.D., HICKMAN, G.D., REASH, R.J. and THOMAS, J.A. Development of a multimetric index for assessing the biological condition of the Ohio River. Transactions of the American Fisheries Society, 2003 , 132(4), 791-808. http://dx.doi.org/10.1577/T01076.

ENVIRONMENTAL PROTECTION AGENCY EPA. Introduction to the clean water act [online]. 2017 [viewed 13 December 2017]. Available from: https://cfpub.epa.gov/watertrain/moduleFrame. cfm?parent_object_id=2569

EUROPEAN COMMUNITY - EC. Directive 2000/60/ EC of the European Parliament and of the Council establishing a Framework for the Community Action in the Field of Water Policy. Journal of European Communication, 2000, L327, 1-72.

EUROPEAN COMMUNITY - EC. Overall approach to the classification of ecological status and ecological potential. Luxembourg: EC, 2005. Guidance document, no 13.

EVERARD, M., FLETCHER, M.S., POWELL, A. and DOBSON, M.K. The feasibility of developing multi-taxa indicators for landscape scale assessment of freshwater systems. Freshwater Reviews, 2011, 4(1), 1-19. http://dx.doi.org/10.1608/FRJ-4.1.129.

FAUSCH, K.D., LYONS, J., KARR, J.R. and ANGERMEIER, P.L. Fish communities as indicators of environmental degradation. American Fisheries Society Symposium, 1990, 8, 123-144.

FERREIRA, M.T., RODRÍGUEZ-GONZÁLEZ, P.M., AGUIAR, F.C. and ALBUQUERQUE, A. Assessing biotic integrity in Iberian rivers: Development of a multimetric plant index. Ecological Indicators, 2005, 5(2), 137-149. http://dx.doi.org/10.1016/j. ecolind.2005.01.001.

FORE, L.S., KARR, J.R. and CONQUEST, L.L. Statistical properties of an index of Biological Integrity used to evaluate Water Resources. Canadian Journal of Aquatic Fisheries Sciences, 1994, 51(5), 1077-1087. http://dx.doi.org/10.1139/f94-107.

GERRITSEN, J., CARLSON, R.E., DYCUS, D.L., FAULKNER, C., GIBSON, G.R., HARCUM, J. and MARKOWITZ, S.A. Lake and reservoir bioassessment and biocriteria. Washington: Office of Water, US Environmental Protection Agency, 2003. Technical Guidance Document, EPA-841-B-98-007. 
HILL, B.H., HERLIHY, A.T., KAUFMANN, P.R., DECELLES, S.J. and BORGH, M.A.V. Assessment of streams of the eastern United States using a periphyton index of biotic integrity. Ecological Indicators, 2003, 2(4), 325-338. http://dx.doi. org/10.1016/S1470-160X(02)00062-6.

HUGHES, R.M., KAUFMANN, P.R., HERLIHY, A.T., KINCAID, T.M., REYNOLDS, L. and LARSEN, D.P. A process for developing and evaluating indices of fish assemblage integrity. Canadian Journal of Fisheries and Aquatic Sciences, 1998, 55(7), 16181631. http://dx.doi.org/10.1139/f98-060.

IRZ, P., ODION, M., ARGILLIER, C. and PONT, D. Comparison between the fish communities of lakes, reservoirs and rivers: can natural systems help define the ecological potential of reservoirs? Aquatic Sciences, 2006, 68(1), 109-116. http://dx.doi.org/10.1007/ s00027-005-0812-3.

JENNINGS, M.J., FORE, L.S. and KARR, J.R. Biological monitoring of fish assemblages in Tennessee Valley reservoirs. Regulated Rivers: Research and Management, 1995, 11(3-4), 263-274. http:// dx.doi.org/10.1002/rrr.3450110303.

JENNINGS, M.J., LYONS, J., EMMONS, E.E., HATZENBELER, G.R., BOZEK, M.A., SIMONSON, T.D., BEARD JUNIOR, T.D. and FAGO, D. Toward the development of an index of biotic integrity for inland lakes in Wisconsin. In: T.P. SIMON, ed. Assessing the sustainability and biological integrity of water resources using fish communities. Boca Raton: CRC Press, 1999, pp. 541-562.

JOY, M.K. and DEATH, R.G. Application of the index of biotic integrity methodology to New Zealand freshwater fish communities. Environmental Management, 2004, 34(3), 415-428. http://dx.doi. org/10.1007/s00267-004-0083-0. PMid:15520898.

KARR, J.R. and CHU, E.W. Restoring life in running waters: better biological monitoring. Washington: Island Press, 1999.

KARR, J.R. and DUDLEY, D.R. Ecological perspective on water quality goals. Environmental Management, 1981, 5(1), 55-68. http://dx.doi.org/10.1007/ BF01866609.

KARR, J.R. Assessment of biotic integrity using fish communities. Fisheries, 1981, 6(6), 21-27. http://dx.doi.org/10.1577/15488446(1981)006<0021:AOBIUF>2.0.CO;2.

KARR, J.R. Seven foundations of biological monitoring and assessment. Biologia Ambientale, 2006, 20, 7-18.

KARR, J.R., FAUSCH, K.D., ANGERMEIER, P.L., YANT, P.R. and SCHLOSSER, I.J. Assessing biological integrity in running waters: a method and its rationale. Illinois Natural History Survey Special Publication, 1986, 5, 1-28.

KLEMM, D.J., BLOCKSOM, K.A., FULK, F.A., HERLIHY, A.T., HUGHES, R.M., KAUFMANN,
P.R., PECK, D.V., STODDARD, J.L., THOENY, W.T., GRIFFITH, M.B. and DAVIS, W.S. Development and Evaluation of a Macroinvertebrate Biotic Integrity Index (MBII) for Regionally Assessing Mid-Atlantic Highlands Streams. Environmental Management, 2003, 31(5), 656-669. http://dx.doi. org/10.1007/s00267-002-2945-7. PMid:12719895.

KLEMM, D.J., BLOCKSOM, K.A., THOENY, W.T., FULK, F.A., HERLIHY, A.T., KAUFMANN, P.R. and CORMIER, S.M. Methods development and use of macroinvertebrates as indicators of ecological conditions for streams in the mid-atlantic highlands region. Environmental Monitoring and Assessment, 2002, 78(2), 169-212. http://dx.doi. org/10.1023/A:1016363718037. PMid:12229921.

KREBS, C. J. Ecological methodology. 2. ed. San Francisco: Benjamin Cummings, 1999.

LOUGHEED, V.L., PARKER, C.A. and STEVENSON, R.J. Using non-linear responses of multiple taxonomic groups to establish criteria indicative of wetland biological condition. Wetlands, 2007, 27(1), 96-109. http://dx.doi.org/10.1672/02775212(2007)27[96:UNROMT]2.0.CO;2.

MAGALHÁES, M.F., RAMALHO, C.E. and COLLARES-PEREIRA, M.J. Assessing biotic integrity in a Mediterranean watershed: development and evaluation of a fish-based index. Fisheries Management and Ecology, 2008, 15(4), 273-289. http://dx.doi.org/10.1111/j.13652400.2008.00612.x.

MCCORMICK, R.M., HUGHES, R.M., KAUFMANN, P.M., PECK, D.V., STODDARD, J.L. and HERLIHY, A.T. Development of an index of biotic integrity for the mid-atlantic highlands region. Transactions of the American Fisheries Society, 2001, 130(5), 857-877. http://dx.doi.org/10.1577/15488659(2001) $130<0857:$ DOAIOB $>2.0 . C O ; 2$.

MCDONOUGH, T.A. and HICKMAN, G.D. Reservoir fish assemblage index development: a tool for assessing ecological health in Tennessee Valley Authority impoundments. In: T.P. SIMON, ed. Assessing the sustainability and Biological Integrity of water resources using fish communities. Boca Raton: CRC Press, 1999, pp. 523-540.

OLIVEIRA, B.S.R., CASTRO, C.M. and BAPTISTA, D.F. Desenvolvimento de índices multimétricos para utilização em programas de monitoramento biológico da integridade de ecossistemas aquáticos. Oecologia Brasiliensis, 2008, 12(3), 463-486.

PETESSE, M.L., PETRERE JUNIOR, M. and AGOSTINHO, Â.A. Defining a fish bio-assessment tool to monitoring the biological condition of a cascade reservoirs system in tropical area. Ecological Engineering, 2014, 69, 139-150. http://dx.doi. org/10.1016/j.ecoleng.2014.03.070.

PETESSE, M.L., PETRERE, M. and SPIGOLON, R.J. Adaptation of the Reservoir Fish Assemblage Index 
(RFAI) for assessing the Barra Bonita Reservoir (São Paulo, Brazil). River Research and Applications, 2007, 23(6), 595-612. http://dx.doi.org/10.1002/rra.1001.

RUARO, R. and GUBIANI, E.A. A scientometric assessment of 30 years of the Index of Biotic Integrity in aquatic ecosystems: applications and main flaws. Ecological Indicators, 2013, 29, 105-110. http:// dx.doi.org/10.1016/j.ecolind.2012.12.016.

STEVENS JUNIOR, D.L. and OLSEN, A.R. Spatially balanced sampling of natural resources. Journal of the American Statistical Association, 2004, 99(465), 262-278. http://dx.doi. org/10.1198/016214504000000250.

STODDARD, J.L., LARSEN, D.P., HAWKINS, C.P., JOHNSON, R.K. and NORRIS, R.H. Setting expectations for the ecological condition of streams: the concept of reference condition. Ecological Applications, 2006, 16(4), 1267-1276. http://dx.doi. org/10.1890/1051-0761(2006)016[1267:SEFTEC] 2.0.CO;2. PMid:16937796.

STRAŠKRABA, M. and TUNDISI, J.G. Reservoir ecosystem functioning: theory and application. In: J.G. TUNDISI, and M. STRAŠKRABA, eds. Theoretical reservoir ecology and its applications. São Carlos: IIE, 1999. pp. 565-583.

TERRA, B.F. and ARAÚJO, F.G. A preliminary fish assemblage index for a transitional river-reservoir system in southeastern Brazil. Ecological Indicators,
2011, 11(3), 874-881. http://dx.doi.org/10.1016/j. ecolind.2010.11.006.

TERRA, B.F., HUGHES, R.M., FRANCELINO, M.R. and ARAÚJO, F.G. Assessment of biotic condition of Atlantic Rain Forest streams: A fishbased multimetric approach. Ecological Indicators, 2013, 34, 136-148. http://dx.doi.org/10.1016/j. ecolind.2013.05.001.

UZARSKI, D.G., BURTON, T.M., COOPER, M.J., INGRAM, J.W. and TIMMERMANS, S.T.A. Fish habitat use within and across wetland classes in coastal wetlands of the five Great Lakes: development of a fish-based index of biotic integrity. Journal of Great Lakes Research, 2005, 31(1), 171-187. http://dx.doi. org/10.1016/S0380-1330(05)70297-5.

WHITTIER, T.R. Development of IBI metrics for lakes in Southern New England. In: T.P. SIMON, ed. Assessing the sustainability and biological integrity of water resources using fish communities. Boca Raton: CRC Press, 1999, pp. 563-582.

WU, N., SCHMALZ, B. and FOHRER, N. Development and testing of a phytoplankton index of biotic integrity (P-IBI) for a German lowland river. Ecological Indicators, 2012, 13(1), 158-167. http:// dx.doi.org/10.1016/j.ecolind.2011.05.022.

Received: 13 December 2017 Accepted: 03 October 2018 